\section{How does resetting intraocular pressure help optic nerve function?}

There are two quite separate parts of this article: the first deals with fact, the second, theory. The subject is whether a resetting of the level of intraocular pressure (IOP) has a beneficial effect in glaucoma, and if so, how it causes a benefit. Regarding fact, it has been known since 1869 that lowering IOP can benefit a person - such as Katherina - with glaucoma, in whom disappearance of headache and improvement in appearance of the optic nerve head were the consequence of lowering pressure. ${ }^{1}$ It is now known that 'improvement' in disc topography is a common occurrence following lowering of the IOP ${ }^{1-12}$ and that improvement in visual function also occurs. ${ }^{5,13-22}$ This is established fact. Much, however, is not established:

- In whom will such improvement occur?

- What predisposes to such improvement?

- What are the mechanisms that account for the improvement?

Evidence of improvement is seen both in individuals and in populations. The improvement caused by lowering IOP from $80 \mathrm{mmHg}$ to $15 \mathrm{mmHg}$, in a person in whom IOP acutely went from 15 to $80 \mathrm{mmHg}$, is obvious to all. But the matter to be considered here is whether lowering IOP is of benefit in chronic glaucoma with lesser magnitudes of pressure elevation. Let us define our terms so we can communicate most clearly:

G.L. Spaeth

M.L. Marques Pereira

William and Anna Goldberg

Glaucoma Service \&

Research Laboratories

Wills Eye Hospital

Philadelphia

Pennsylvania, USA

\section{G.L. Spaeth}

Professor of Ophthalmology Jefferson Medical College

Philadelphia

PA 19107, USA

George L. Spaeth, MD

Wills Eye Hospital

900 Walnut Street

Philadelphia

PA 19107, USA

Tel: +1 (215) 9283197

Fax: + 1 (215) 9280166

e-mail: kparker@hslc.org
Glaucoma Glaucoma is ocular tissue damage at least partly related to pressure within the eye. This is an arbitrary definition, but if the pressure-related aspect is removed, every case of an optic neuropathy becomes glaucoma. If loss of function must be present to have 'glaucoma' one eliminates the evolving stages of the disease, and considers only the late stages of the condition, because topographical change precedes functional change.

Improvement A careful distinction must be made between an improvement in a finding and an improvement in function, cellular or personal. These are related, but different measures. For example, the rim area of the disc may become thicker or the cup shallower, but that does not prove that neurones function better or that the person sees better. By 'improvement', here, we mean a return towards presumed normal in whatever is being considered: disc topography, electrical responsiveness, visual field, etc. But it should be stressed that the relationship between the different measures is complex: the disc can 'improve' topographically at the same time as the visual field is deteriorating, and the disc may seem structurally unchanged despite improvement in the visual field.

\section{Evidence that glaucoma improves when IOP is} lowered

\section{Optic disc topography}

An improvement in the appearance of the optic disc of humans, manifested by a decrease in the diameter of the cup, shallowing of the cup, decrease in cup volume, widening of the neural rim, and a decrease in signs of venous stasis, can occur consequential to lowering IOPs. ${ }^{2-12}$ Such improvement is common, indeed routine, in infants with cupping caused by elevated intraocular pressure, ${ }^{23,24}$ but it also occurs in adults, including the elderly (Figs. 1,2). Factors associated with such an improvement suggest mechanisms to account for the change (Table 3).

The appearance of the disc varies ${ }^{25}$ and is related to its diameter (the circumference of the scleral ring), the anterior-posterior position of the lamina, the curvature of the lamina, the number and size of the optic neurons, the amount and nature of other cellular material (astroglia), the extracellular material and the vascularity (Table 2 ).

The position of the anterior portion of the optic nerve is a function of the pressure within the eye anterior to the lamina cribrosa, the pressure posterior to the lamina cribrosa, and the compliance of the lamina cribrosa. The disc is a plastic structure, related to the presence of elastin in the lamina. With increasing age the amount of elastin decreases. Also, the nature of collagen changes with age and perhaps with the presence of glaucoma. ${ }^{26-29}$ Changes in IOP, then, either up or down, can be associated with changes in the position of the lamina cribrosa. ${ }^{30-33}$ In the enucleated eye, raising IOP from 5 to $50 \mathrm{mmHg}$ displaces the surface of the optic nerve head $36 \mu \mathrm{m}$ posteriorly. ${ }^{31}$ As the lamina moves anteriorly or posteriorly, it has the capacity to traumatise neurones directly by 


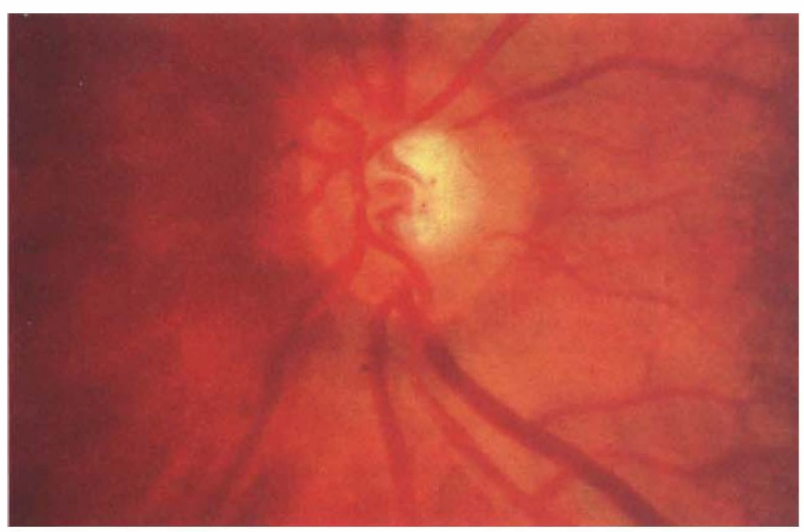

(a)

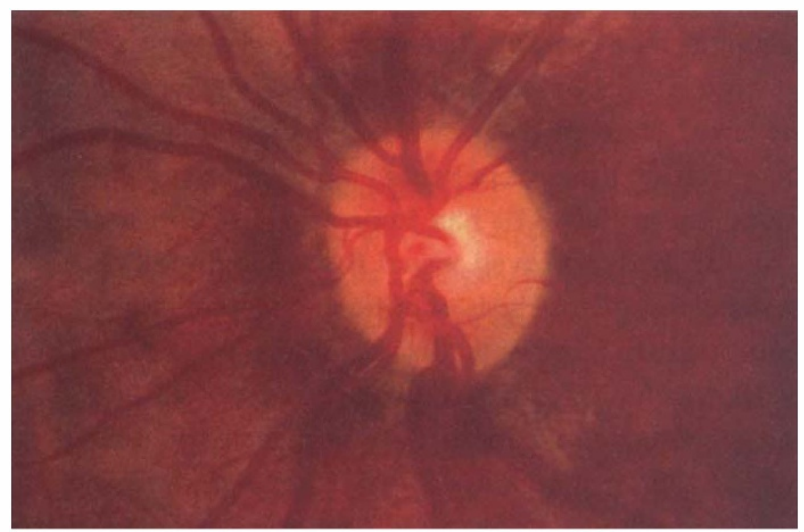

(c)

compression injury or traction on straight or kinked neurones, ${ }^{34}$ or indirectly due to arterial ischaemia or venous stasis. ${ }^{35-42}$ Lowering IOP, then, may presumably exert a beneficial effect if the anterior optic nerve has been posteriorly displaced secondary to IOP. The absolute level of IOP may be immaterial. The critical factors are the relationship between the level of IOP anterior to and posterior to the lamina, and the ability of that lamina to be deformed due to its compliance characteristics. Laminar deformation may also have effects on the vessels that pass through the tissues, and a restoration of the normal position of the lamina may be associated with improved haemodynamics, assuming vascular changes are not permanent.

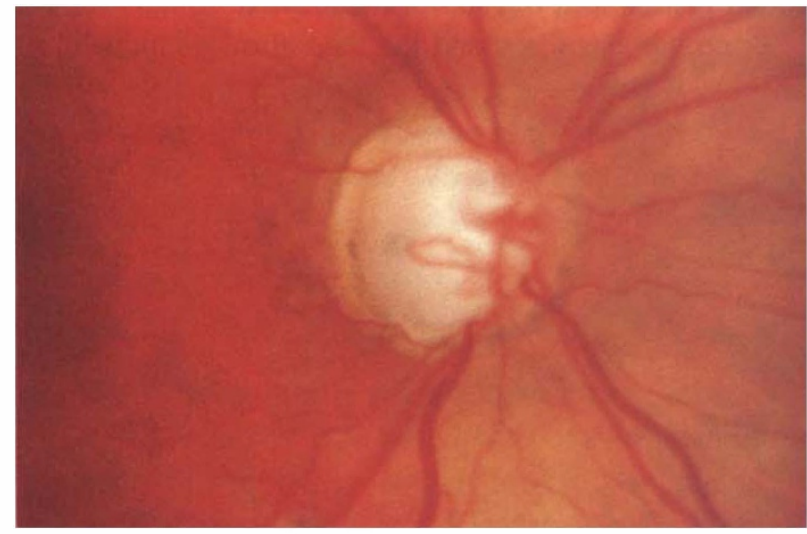

(a)

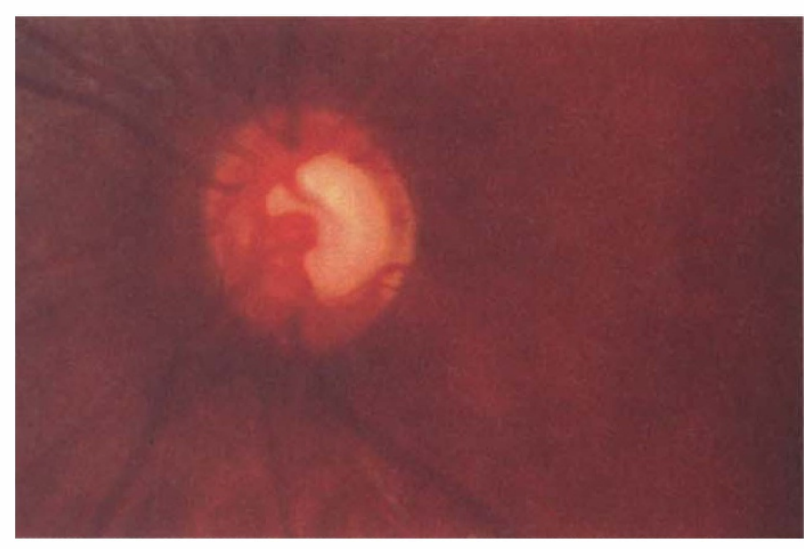

(b)

Fig. 1. Concentric cupping becoming worse with IOP near $40 \mathrm{mmHg}$ $(a, b)$, but becoming less post-operatively when IOP pressure was 18 $m m H g(c$, taken 2 years after $b)$.

The size of the optic cup is related to the size of the optic nerve head. ${ }^{43} \mathrm{~A}$ decrease in the size of the scleral ring, with a consequent decrease in the diameter of the optic nerve head, can occur, especially in infants, following lowering of IOP. ${ }^{23}$ Thus, improvement in disc topography in infants following a decrease in IOP is a combination of anterior movement of the lamina and a decrease in disc size. This mechanism has not been extensively studied in adults, but is certainly less of a factor than in infants.

The width of the neural rim of the optic nerve is a function of the size of the scleral ring and the number and nature of the neurones. The scleral ring can be affected by IOP, as already discussed. ${ }^{23}$ Most normal

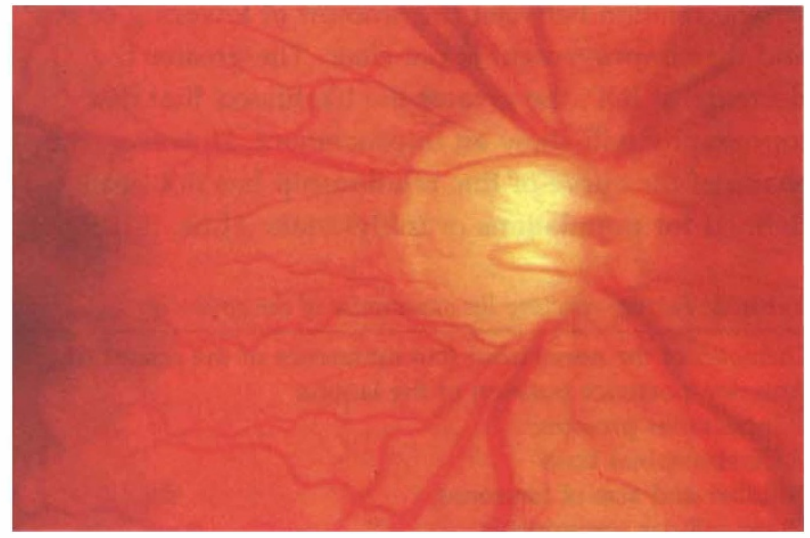

(b)

Fig. 2. (a), (b) The optic disc of this 60-year-old man showed less cupping following reduction of IOP (b). 
Table 1. Factors predisposing to improvement of optic disc topography

Young age

Short duration of optic disc damage

Marked fall in intraocular pressure

Less advanced optic disc damage

Concentric cupping without focal change of optic disc

eyes have roughly the same number of optic neurones; this number decreases with age. ${ }^{4-47}$ The neural ring may become thinner in advancing age because of this apparently obligatory loss of neurones, although this change, if real, is not marked. ${ }^{48}$ It is logical to assume that damaged neurones that recover when the damaging factors are relieved may regain their normal bulk, and, as such, cause a thickening of the neural rim.

Astroglia comprise a portion of the optic nerve head tissue. ${ }^{49}$ These cells are also damaged by factors that affect the neurones. ${ }^{50}$ As they recover, which they presumably do when damage is not fatal, they may cause a decrease in cupping. In patients with far-advanced damage such a change appears to occur occasionally, as demonstrated by a marked 'filling in' of the cup, usually unassociated with improvement in visual function (Fig. 3).

Acute oedema may cause an immediate decrease in 'cupping' following a decrease in IOP (Fig. 4). While this tends to be more prominent in eyes with lesser degrees of disc change, it can occur in eyes with advanced optic nerve damage. ${ }^{51}$

Lastly, the possibility of neuronal neogenesis can no longer be dismissed, since several investigators have now established that central nervous systems neurones can regenerate. ${ }^{52,53}$ This, however, is not a likely explanation for the topographic improvement in adults.

Discs which deteriorate by concentric cupping (Fig. 1) are more likely to show improvement than those with focal changes (Figs. 5, 6). Experimental glaucoma caused by elevating IOP usually causes concentric cupping, rather than focal loss. It may be, then, that concentric cupping represents a mechanical type of disc damage and that elimination of the mechanical cause (elevated IOP) therefore allows the plastic nerve head to recover. With focal changes the pathology is presumably not just pressure-elevation related, so that displacement of the lamina may play less of a role in these cases.

The relation between the amount of lowering of IOP and disc improvement is not clear. The greater the decrease in IOP, the greater the likelihood that disc topography will show an improvement. However, the shape of the curve of this relationship has not been defined for populations or individuals. Thus, it has not

Table 2. Factors affecting the appearance of the optic disc

Diameter of the nerve head (circumference of the scleral ring)
Anterior-posterior position of the lamina
Intraocular pressure
Cerebrospinal fluid
Number and size of neurones
Other cellular components
Extracellular considerations
Vascularity

Table 3. Mechanisms for improvement in disc appearance, in association with lowering of intraocular pressure

Anterior displacement of lamina cribrosa

Decrease in the diameter of the disc

Healing of damage neurones

Increase in connective tissue (late)

Oedema (early and transient)

Oedema (chronic with hypotony)

Neogenesis of neurones

been established that lowering IOP by, for example, $15 \mathrm{mmHg}$ is more beneficial in a particular specific population or particular individual than lowering IOP by $5 \mathrm{mmHg}$. It is also not known whether considering the lowering in terms of a percentage of absolute fall is more relevant. However, improvement appears to be unlikely when IOP falls by less than $30 \% .^{5}$ One study, which reviewed stereophotographs and visual fields, demonstrated that of patients having at least a $30 \%$ reduction in IOP, 30\% had improved disc appearance and $40 \%$ had improved visual fields. ${ }^{5}$ In another study, using computer analysis of optic disc stereophotographs, improvement in all optic disc parameters was found in 8 of 13 eyes having a mean IOP reduction of $48 \% .^{6}$ Using the same technique another study detected increased neuroretinal rim area in $44 \%$ of patients undergoing glaucoma surgery. ${ }^{7}$ Raitta and colleagues ${ }^{6}$ showed, using the Heidelberg Retina Tomograph (HRT) to study changes in optic disc topography after glaucoma surgery in 9 patients, a reduction in optic disc cup volume in all but one of the eyes that had at least a 30\% IOP reduction. The mean cup depth was reduced significantly for this group after 3.7 months of follow-up. The cup:disc ratio was significantly reduced for a subgroup of patients after 12 months, and the surface height of the retinal nerve fibre layer was increased. However, no significant correlation between the amount of fall of IOP and the presence of a disc improvement, was found, ${ }^{14}$ in agreement with the results of Lesk and colleagues ${ }^{11}$ and Irak and colleagues. ${ }^{9}$ Thus, there is an unclear relationship between change in disc appearance and the amount of pressure lowering. It appears clinically that lowering pressure below about $8 \mathrm{mmHg}$ does not give added benefit, but this is not established.

Burgoyne has discussed the theoretical relationships between IOP and cupping, ${ }^{32,52}$ reminding us that even 'normal' IOP constitutes a substantial force on the neurones and the connective tissue.

\section{Nerve fibre layer}

The thickness of the retinal nerve fibre layer is related to the number of retinal ganglion cells. ${ }^{53} \mathrm{~A}$ change in thickness, then, may reflect a change in the number of ganglion cells. Lowering IOP has been associated with increase in nerve fibre layer thickness, ${ }^{6,54,55}$ which may be a sign of an increased number of ganglion cells. 


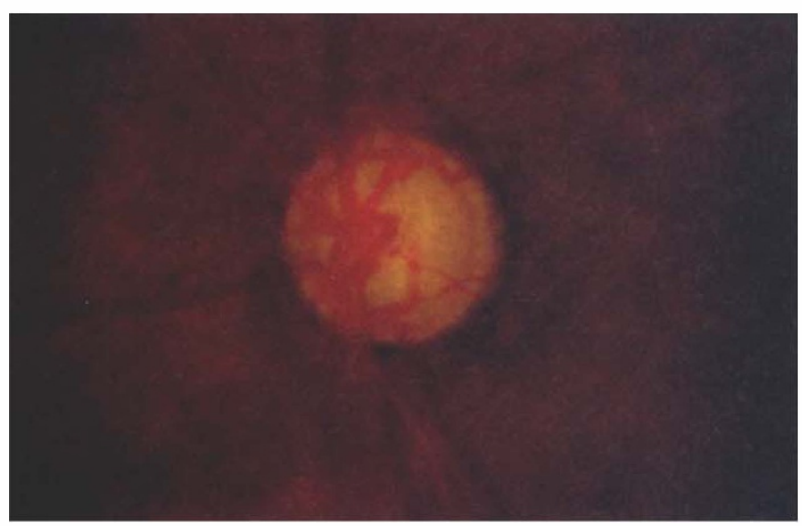

(a)

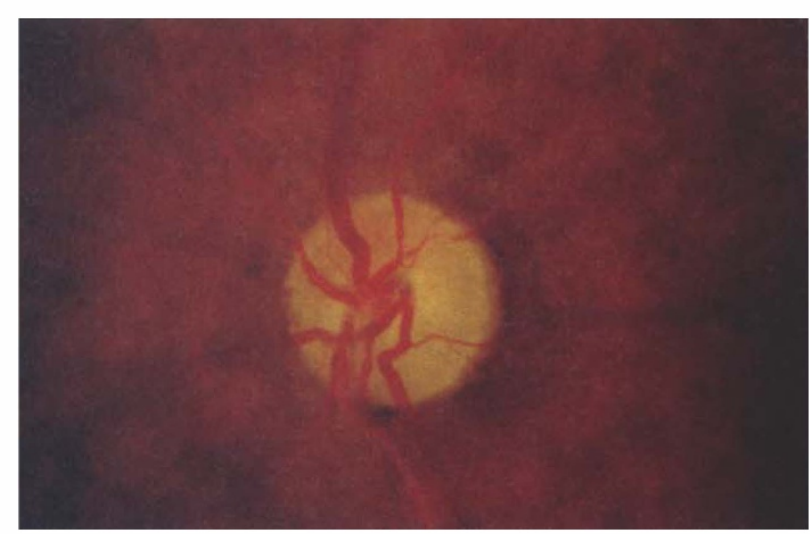

(b)

Fig. 3. $(a),(b)$ There is an apparent improvement in the disc, with less cupping following lowering of the IOP (b) in a woman in her seventies. The 'filling-in' of the cup took years to develop, during which time the visual field worsened.

\section{Visual field}

Many authors have noted improvement in the visual field in association with lowering of IOP. ${ }^{5,14-20}$ This may occur in response to acute changes, such as with single drop therapy ${ }^{13}$ or single doses of an oral carbonic anhydrase inhibitor. ${ }^{14}$ Changes may also occur chronically. A relation between the amount of lowering of IOP and the amount of visual field improvement has been shown. ${ }^{19}$ Whether these apparent improvements are real is complicated by the normal variability of visual field testing results, the learning curve of the subject being tested, psychic changes, and difficulties in

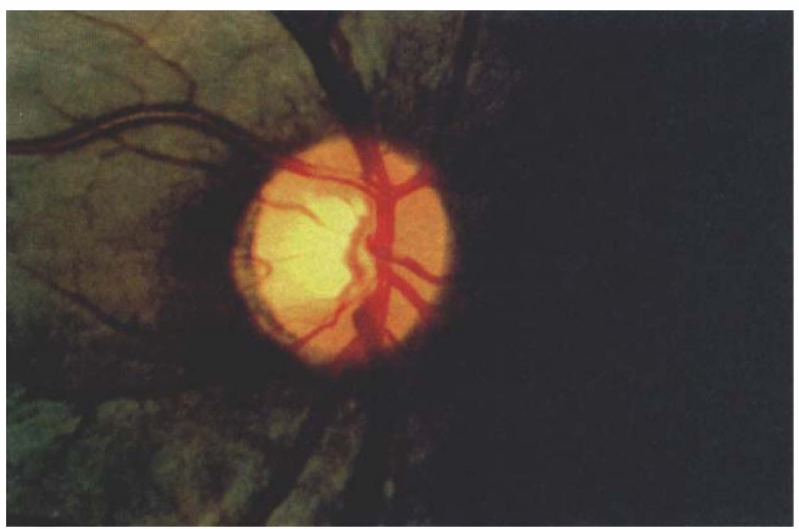

(a)

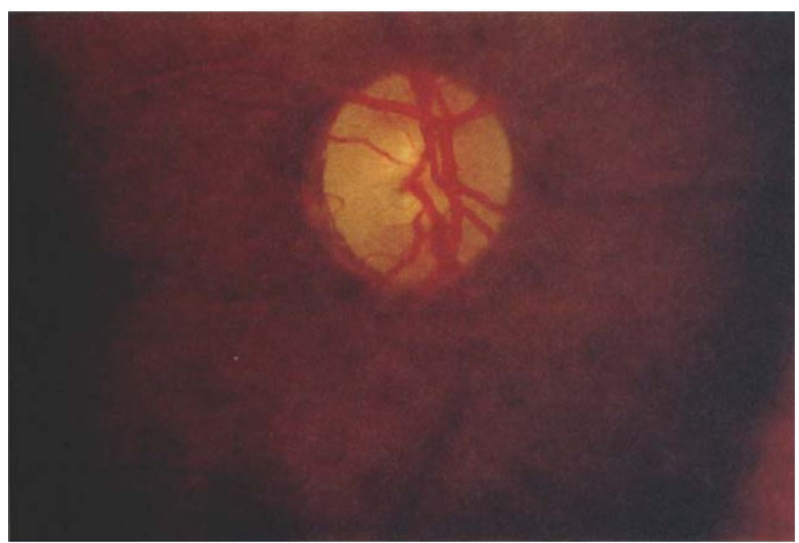

(c) interpretation. Because of this variability the changes in the field must be great or the number of patients showing an improvement must be great for such changes to be considered real. Nevertheless studies such as the Glaucoma Laser Trial (GLT) ${ }^{21,22}$ strongly suggest that chronic treatment can be associated with improvement in the visual fields in patients with moderate or early primary open-angle glaucoma. In the GLT eyes were randomised to initial therapy with laser or medication. Both groups showed a reduction in IOP in response to treatment, though the eyes initially treated with laser trabeculoplasty had a statistically greater reduction than eyes initially treated with medication. ${ }^{31}$ Both groups also

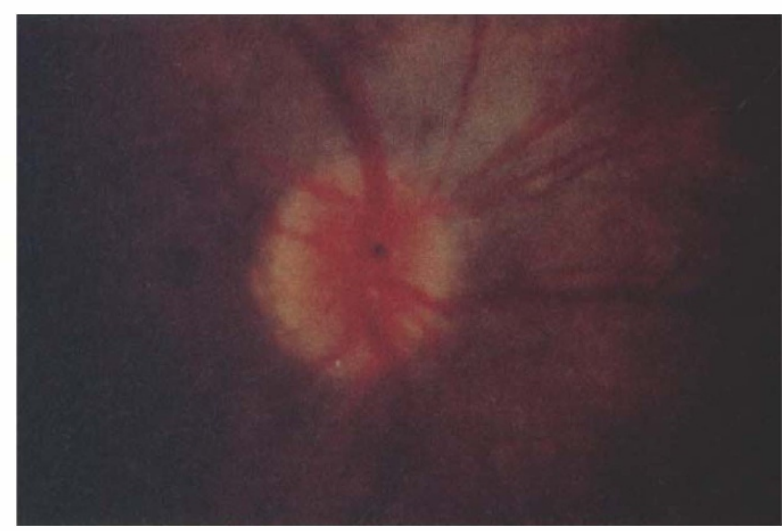

(b)

Fig. 4. (a)-(c) Transient oedema of the disc (b) may occur following lowering of IOP, and needs to be distinguished from lasting change, as seen in (c). 


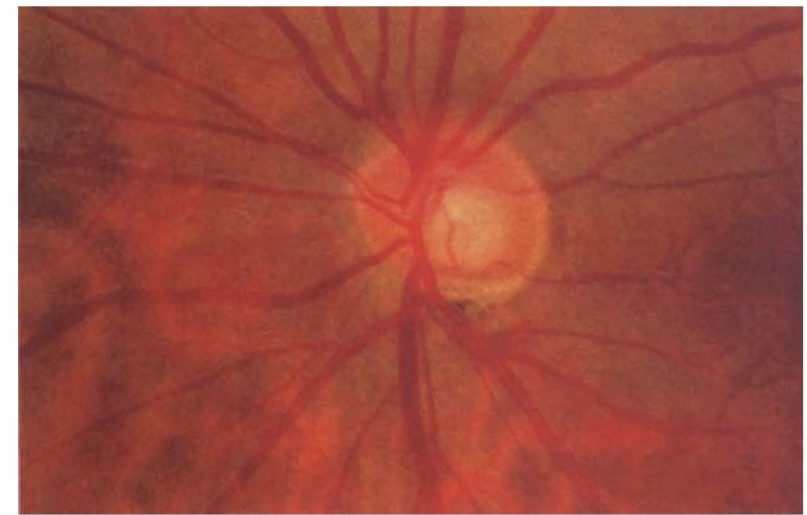

(a)

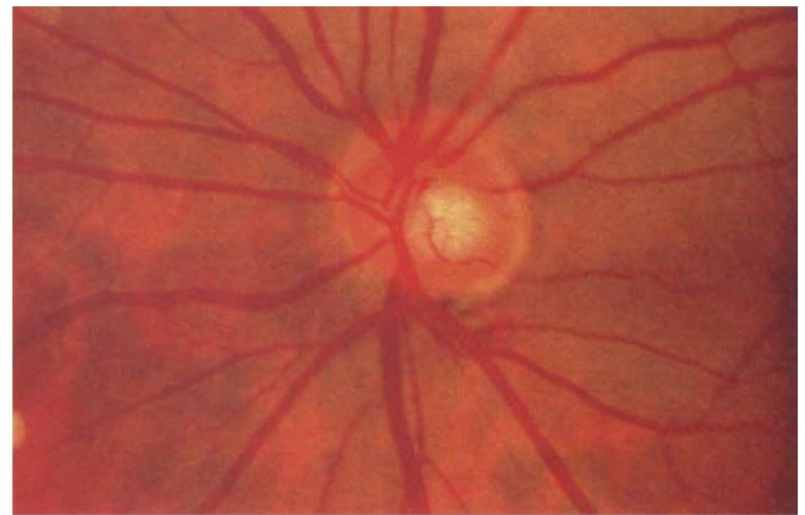

(b)

Fig. 5. (a), (b) Widening of the rim may occur in some patients with focal change.
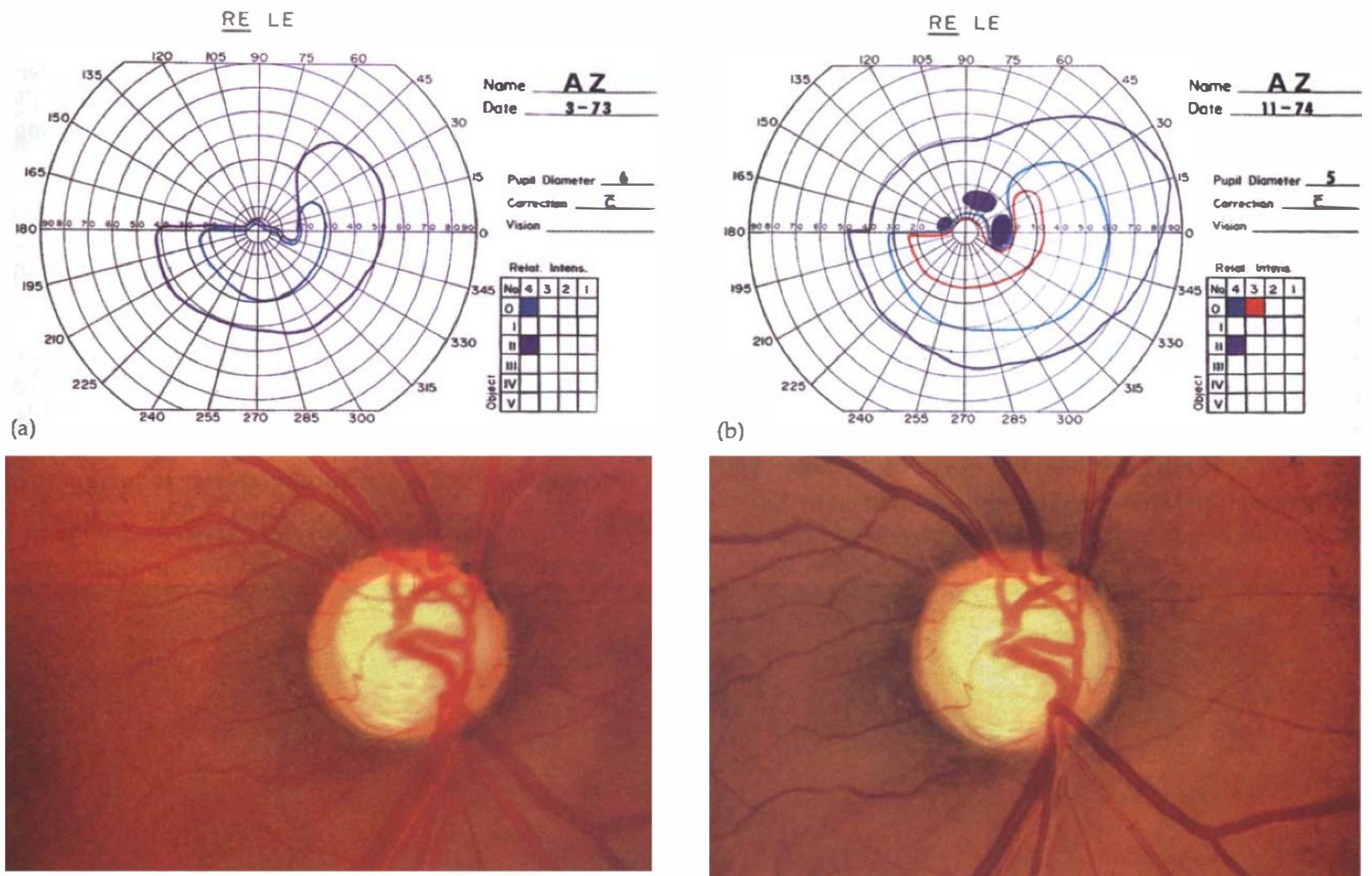

(c)

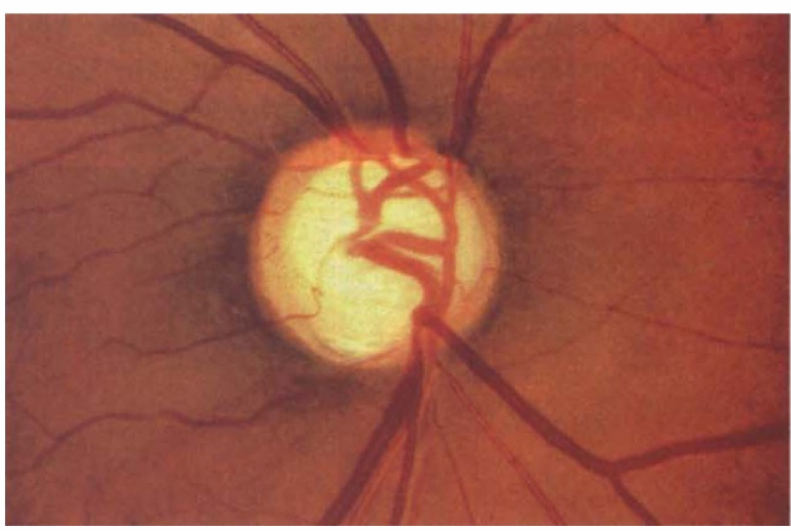

(d)

Fig. 6. (a-d) When focal cupping is marked, improvement in disc appearance may not be noted, even in the face of substantial improvement in the visual field.

showed a statistically significant improvement in visual field, and this was significantly greater in the eyes with the greater lowering of IOP. The two groups were in other ways comparable, suggesting that the greater improvement in visual field was a consequence of the greater lowering of IOP. ${ }^{31}$ Presumed mechanisms for improvement in visual field are listed in Table 4.

Table 4. Mechanisms for improvement in the visual field

Relief of direct compression of neurones

Relief of 'kinking'

Restoration of normal blood flow

Restoration of normal nutrition

Removal of waste and toxins

\section{'Resetting' intraocular pressure: 'stabilising' versus 'lowering'}

It is entirely reasonable to believe that stabilisation of IOP may itself decrease the tendency of neurones to be damaged in glaucoma. Neuronal damage may not be

Table 5. Mechanisms for improvement in blood flow in association with 'resetting' of intraocular pressure

Increased perfusion pressure related to lower intraocular pressure Less direct compression of blood vessels

Less compression of vessels due to less distortion of lamina Improved rheology (less clotting, lower viscosity, etc.) Less episodic stretch on vessels and less release of vasoconstrictive agents

Decrease in vascular effects of pharmacological agents used in treatment due to decreased use of these agents 


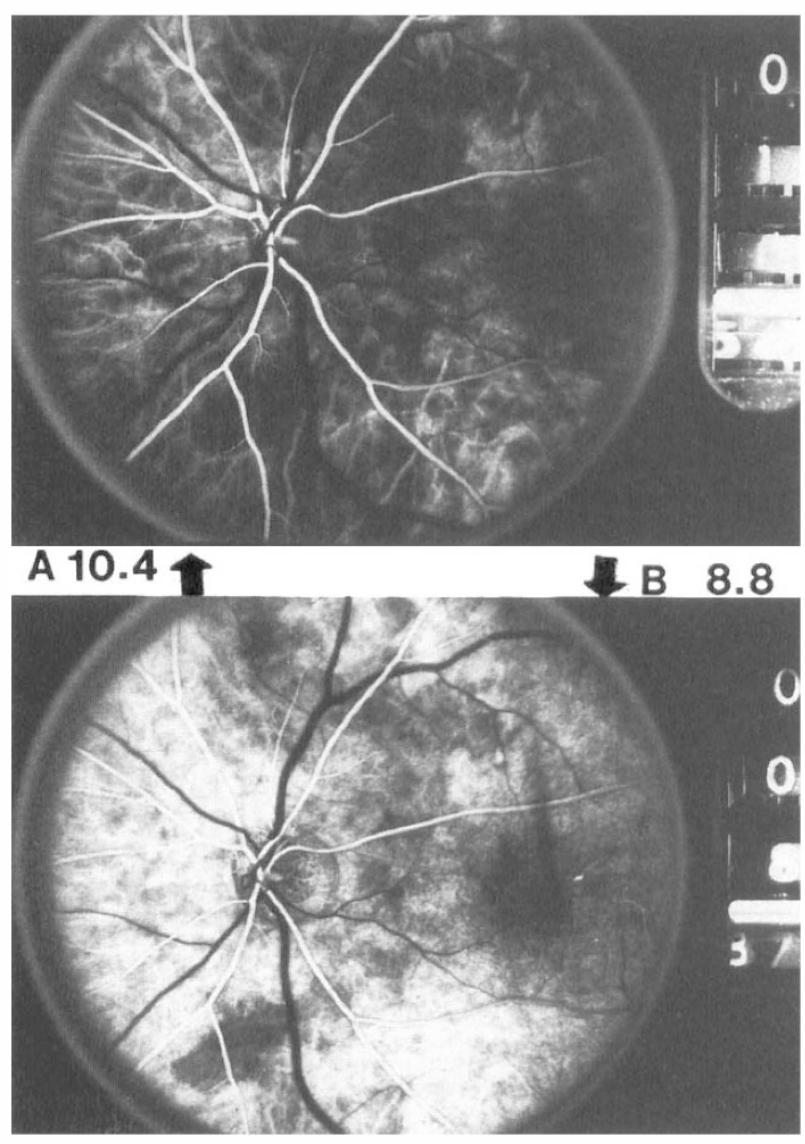

(a)
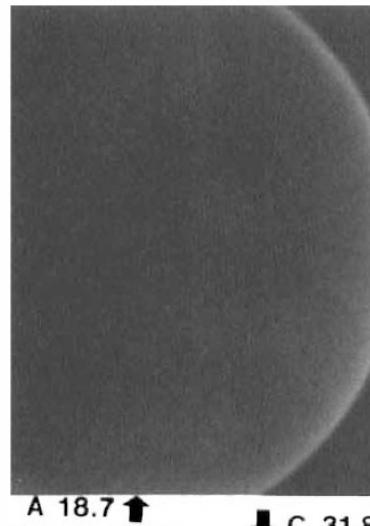

IC 31.8
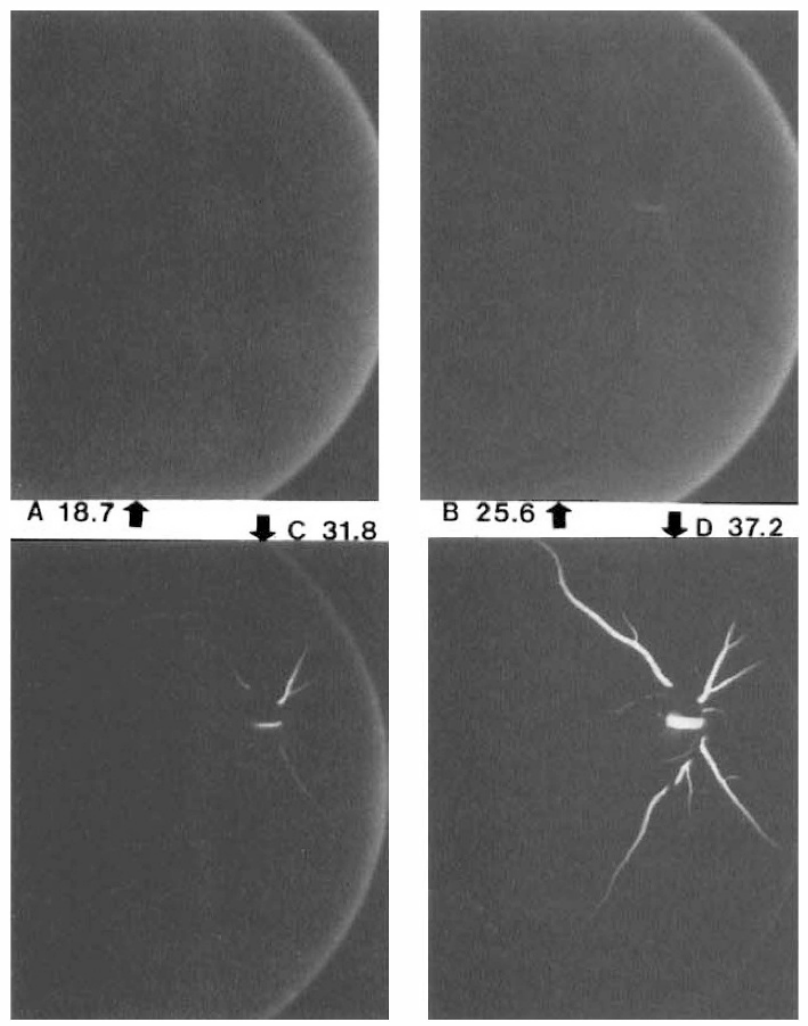

(bi)

solely a function of a pressure 'higher' than the neurones can tolerate, but may theoretically be caused by oscillating IOP. Motion of the anterior surface of the optic nerve, either anteriorly or posteriorly, may stretch the vessels, causing release of endothelial vasoactive
Fig. 7. (a), (b) Fluorescein angiography demonstrated an improvement in blood flow following lowering of IOP in these two adults. Note the more rapid and more complete filling of the optic disc vasculature when IOP pressure was lowered around $50 \%$ from the initial level. (Courtesy of the American Ophthalmological Society.)
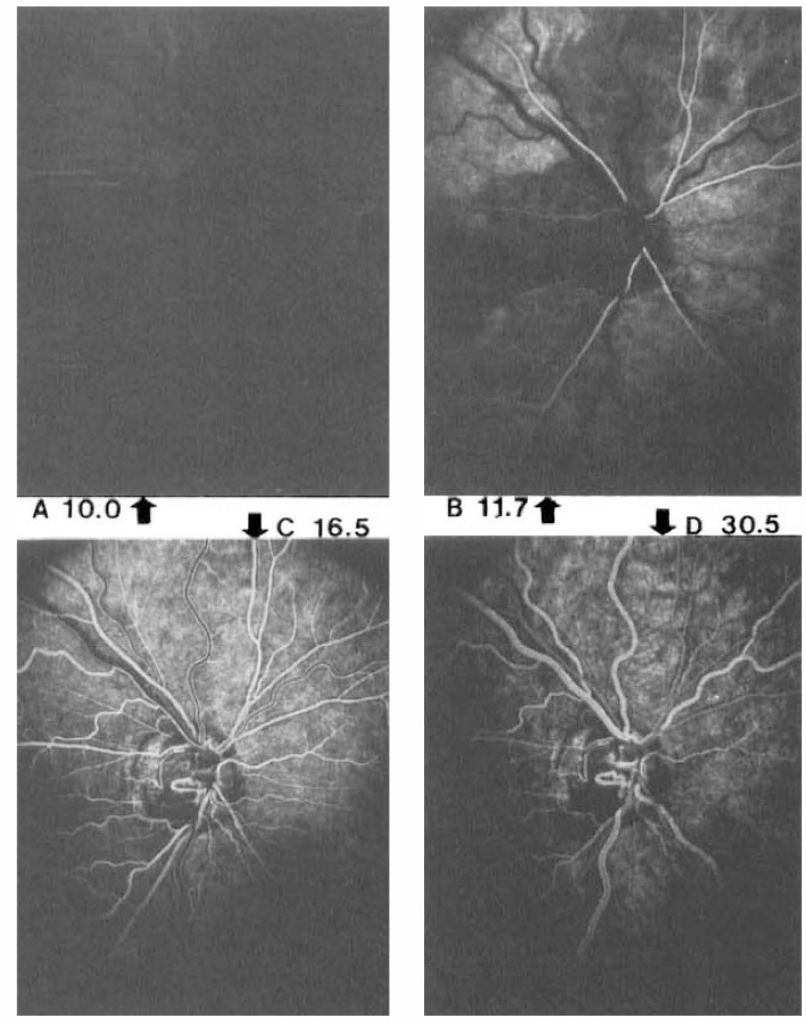

(bii)

substances and consequent localised vasospasm. The vasospasm then becomes the damaging mechanism, but the cause of the vasospasm is the change in the position of the blood vessels caused by the unstable IOP. 

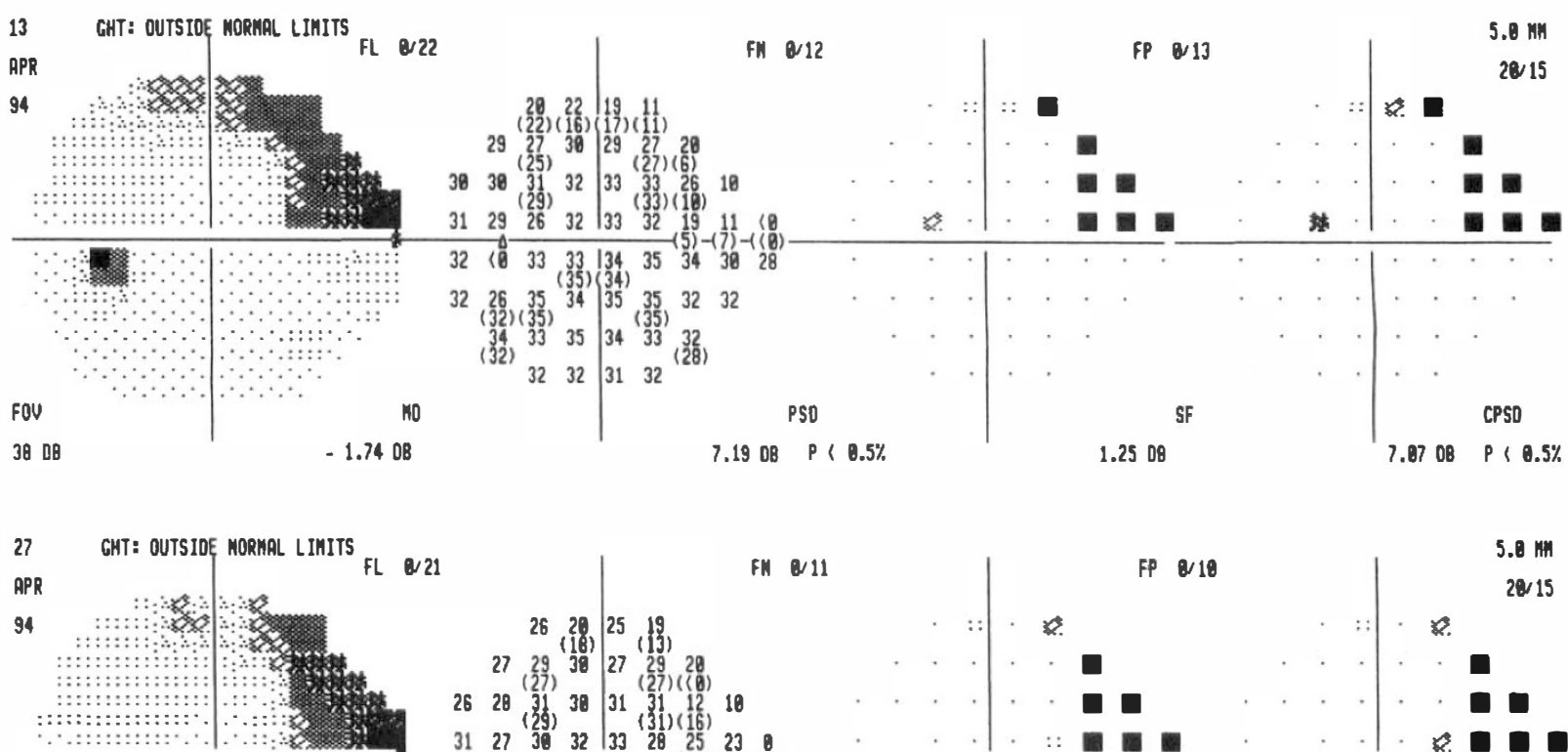

FL 21

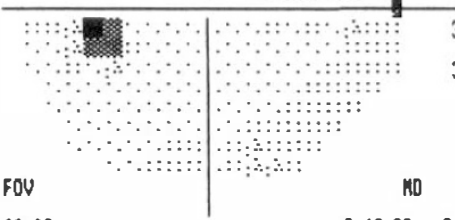

$.2 .4008 P \& 18 \%$

29 (16) 25 (193)

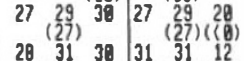

(39) $303131,12 \quad 18$

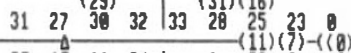

FM Q11 FP $8 / 18$

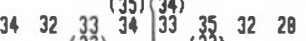

(32) $\begin{array}{lllll}38 & 33 & 32 & 31 & (39) \\ 32 & 28 & 31 & 24\end{array}$

$38 D B$

PSD
6.22 DB $P$ ( $8.5 \%$

$0.97 \mathrm{DB}$

CPSD

$.1308 \quad P<0.5 \%$

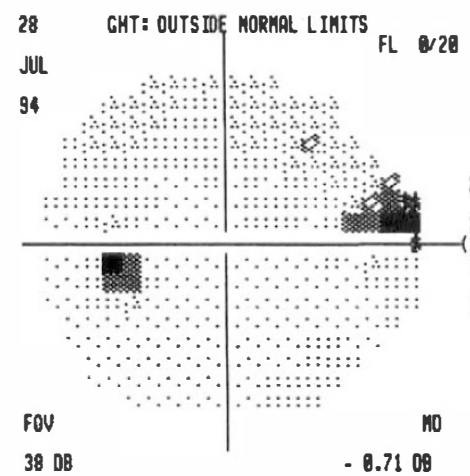

$\mid$ FN 18

FP $1 / 4$

$5.8 \mathrm{MH}$

$28 / 15$

\section{$\begin{array}{llll}24 & 28 & 21 & 23\end{array}$}

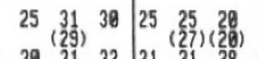

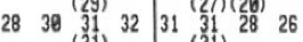

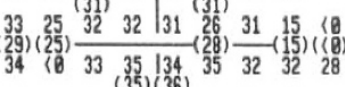

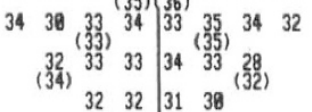

$38 \mathrm{DB}$

4.76 OB PSD $P<1 \%$

$1.23 \mathrm{OB}$

CPSO

58 DQ $P(8.5 \%$

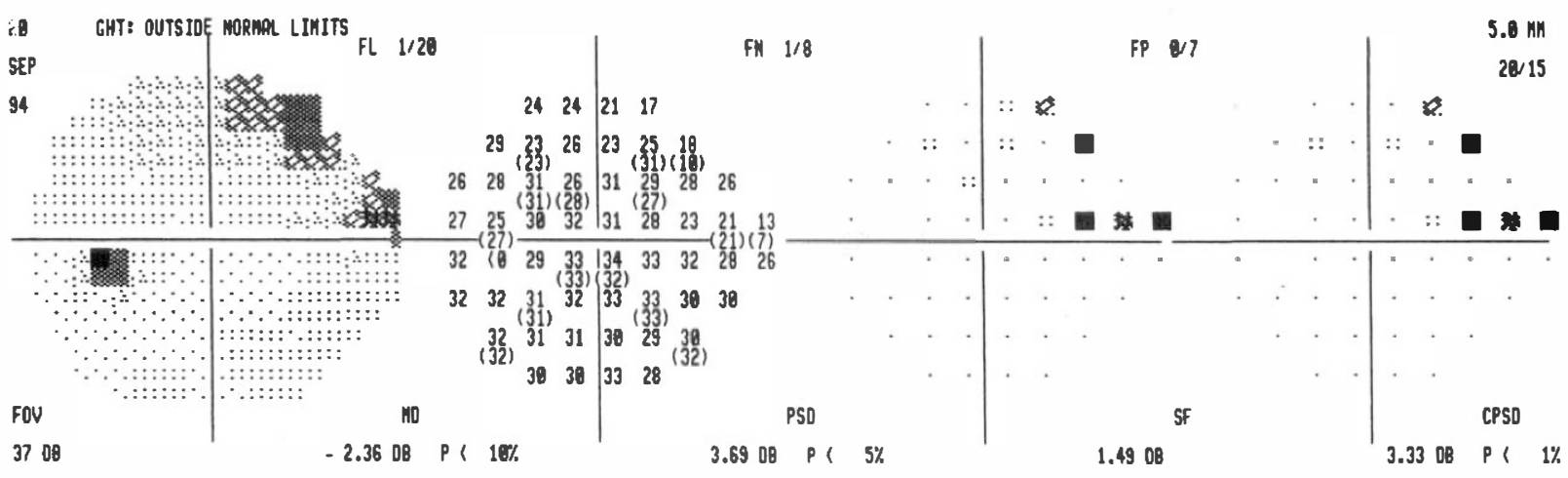

Fig. 8. For legend see p. 485.

Stabilising IOP may also eliminate a 'push-pull' type of compression injury of the neurones. It is entirely possible, then, that an individual may have progressive optic nerve damage when IOPs range between 15 and $25 \mathrm{mmHg}$, with a mean around $20 \mathrm{mmHg}$, and yet not have further deterioration following filtering surgery 


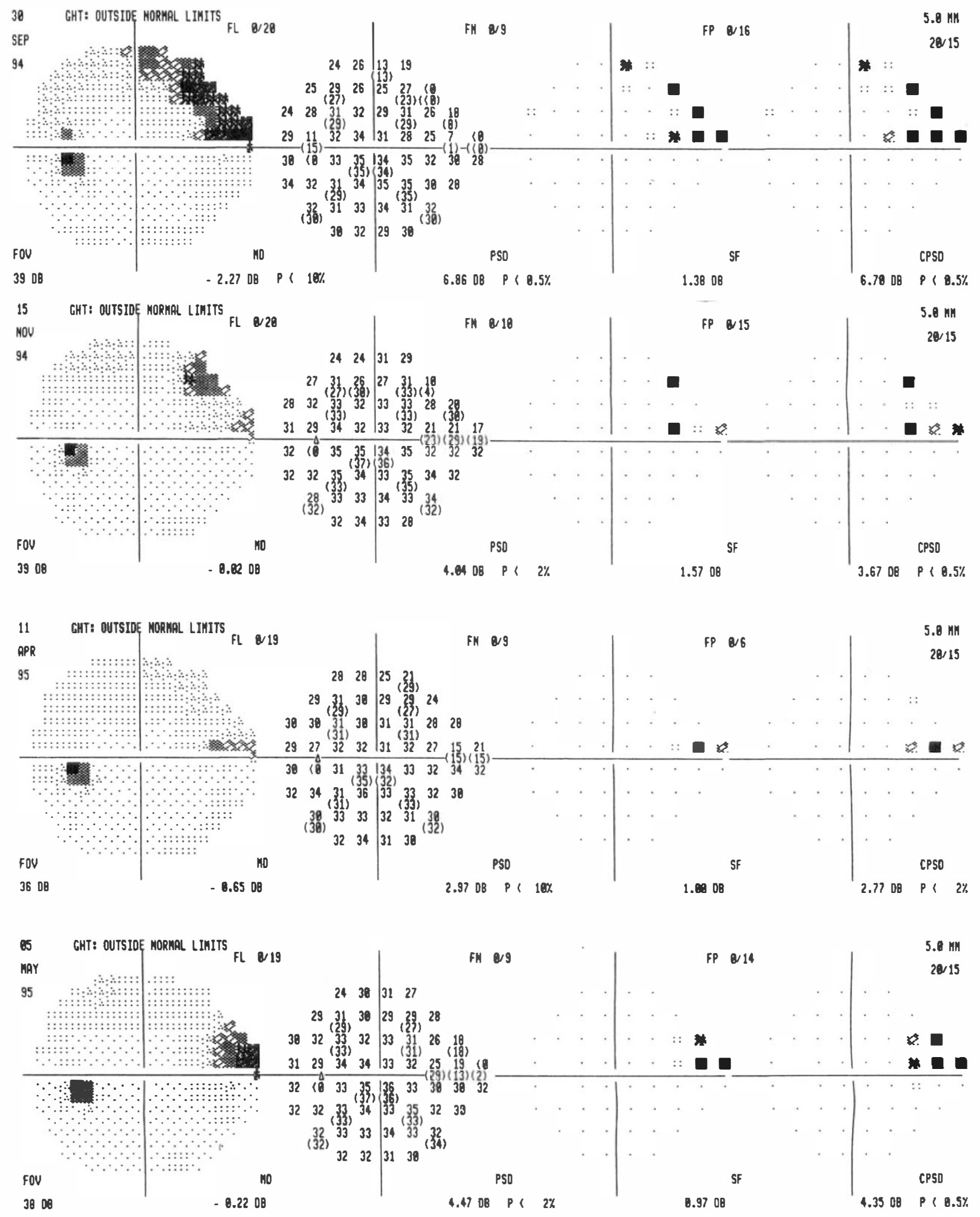

Fig. 8. (contd). For legend see p. 485.

which has resulted in a mean IOP of $20 \mathrm{mmHg}$ with virtually no diurnal variation. A clinical observation is that patients may seem to improve following filtering surgery performed because of progressive field loss due to glaucoma, despite no apparent change in the mean level of IOP following the surgery.

\section{Considerations related to blood flow (Table 5)}

Blood flow to the optic nerve can improve when IOP is lowered $^{35-40}$ (Fig. 7). When IOP is lowered, arterial flow will increase. ${ }^{35}$ This will occur regardless of the level of IOP because, whatever the baseline IOP before it was lowered, that baseline IOP was exerting some gradient of pressure against which the blood entering the eye had to 

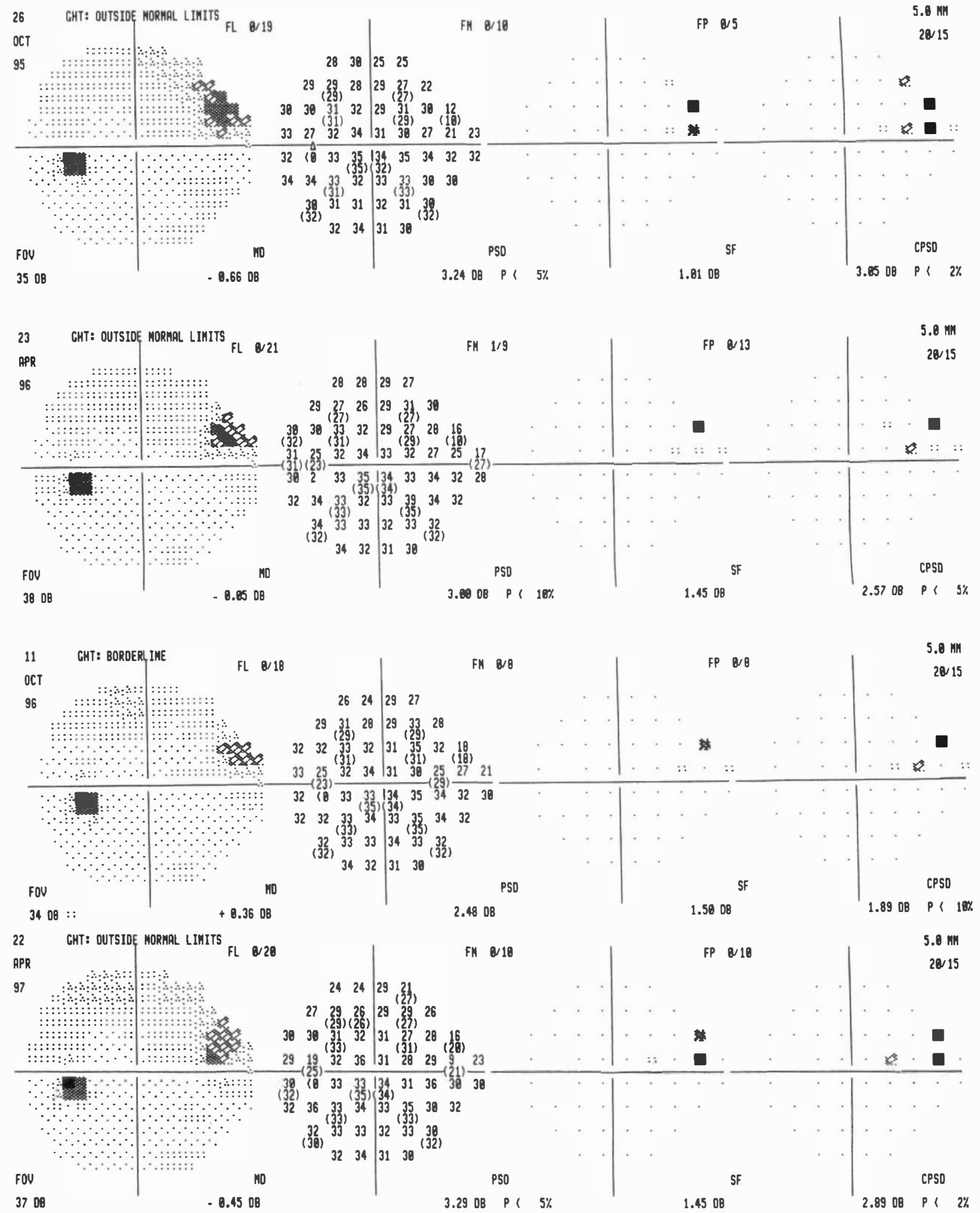

Fig. 8. (contd). For legend see p. 485.

push. Thus, assuming that the blood pressure in the eye in the arterioles entering the eye is $X$, and the IOP is $Y$, the so-called perfusion pressure that will result in blood entering the eye is $X-Y .^{35,37,56}$ Regardless of the initial level of $Y$, the lower $Y$ becomes the greater the perfusion pressure becomes.
If any degree of insufficient nutrition to the neurones is present due to insufficient blood flow, then increasing the perfusion pressure by decreasing IOP pressure will be theoretically of benefit to those neurones. Insufficient blood flow may be the result of disease within the blood vessels, or inadequate nutrients within the blood itself. 

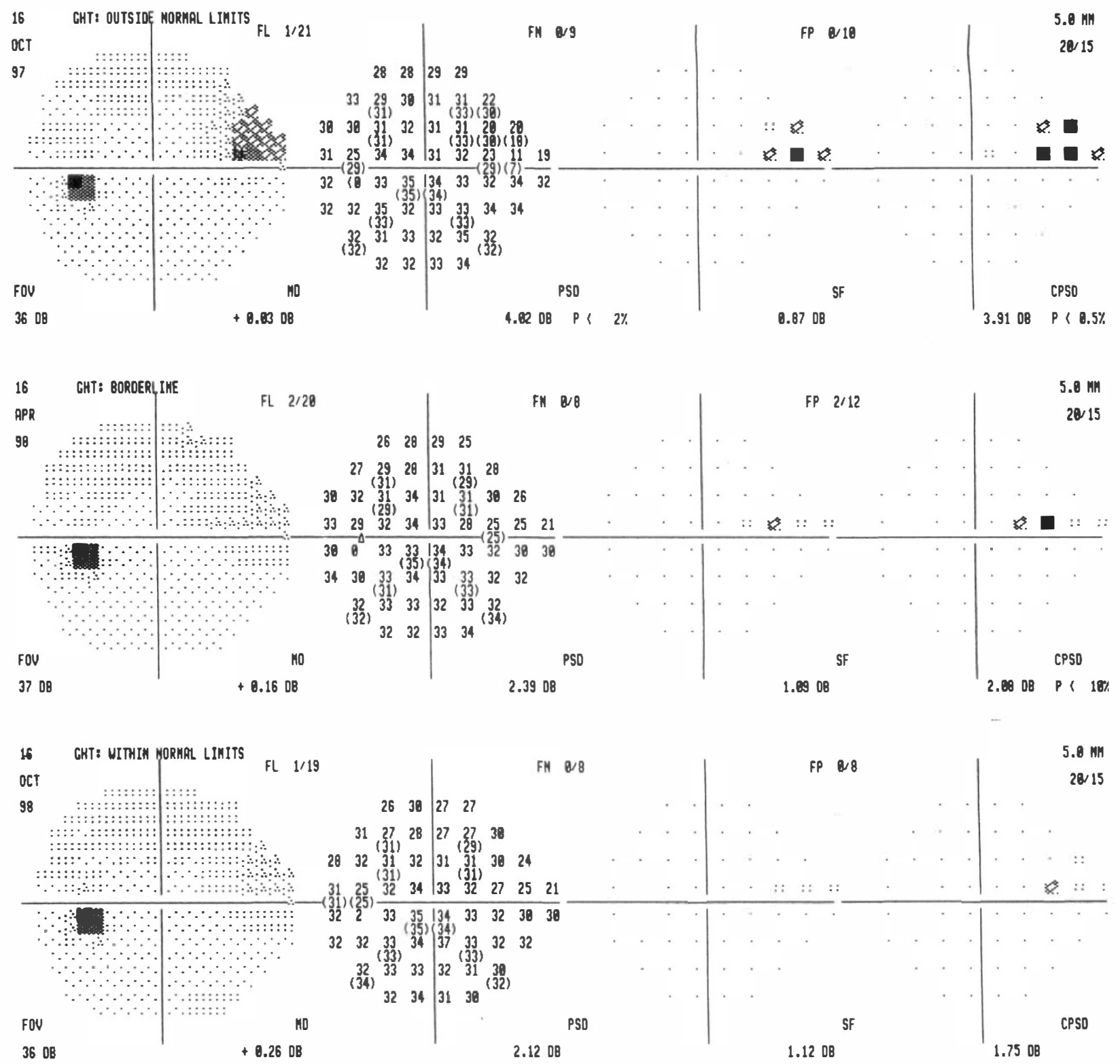

Fig. 8. (contd). Repeated visual field examinations over a 5 year period documented a gradual, total disappearance of a dense defect in this woman with primary open-angle glaucoma, whose IOP was lowered by filtering surgery.

Blood flow may be inadequate due to inappropriate regulation of vessel size and blood flow due to abnormalities of regulation, or local or systemic forces causing decrease in flow. ${ }^{10,36}$ Several factors that may affect the adequacy of the vessel and consequently its autoregulation include: age, atherosclerosis, diabetes, vascular diseases, systemic arterial hypertension or hypotension, use of specific systemic medications, various cardiovascular diseases, and hormones. ${ }^{10,37,38,57}$ Lowering IOP may or may not have a beneficial effect on the abnormality of regulation, but presumably could increase flow due to an increase in perfusion pressure.

Patients with venous-stasis-related IOP will characteristically show a decrease in the venous stasis with lowering of IOP. ${ }^{58-62}$ Lowering IOP may possibly improve the health of the neurones by decreasing the resistance to the venous outflow of blood from the eye. Engorgement of the veins in glaucoma is an established characteristic of some glaucomatous eyes, and a decrease in this engorgement has been noted with a decrease in IOP. The cause for this may be direct compression of the veins or distortion of the lamina causing compression of the central retinal vein.

What is the significance for patients of the fact that discs can improve in appearance and visual function improve following 'resetting' IOP? Studies from different centres confirm the clinical impression of some practitioners that patients with glaucoma characteristically get worse. ${ }^{63-66}$ But patients in whom an improvement is noted are more likely to do better - that is, remain stable or improve in function - regardless of the amount of noted lowering of IOP. ${ }^{67}$ This suggests that using improvement as a measure of 'control' of glaucoma may be more appropriate than using a concept such as target pressure. ${ }^{68,69}$ However, such a method of directing therapy demands use of methods that are 
highly reproducible and highly sensitive in their ability to detect change. Otherwise, patients may be unnecessarily damaged by overzealous attempts to lower IOP.

Perhaps the final frontier in the treatment of glaucoma is a judicious attempt to improve the patient's health. The pattern shown in Fig. 8 suggests that, at least in some patients, this is not an unreasonable goal.

\section{References}

1. von Jaeger E. Ophthalmoskopischer Hand-atlas. Vienna: KK Hof und Staatsdruckere, 1869.

2. Shaffer RN, Hetherington J. The glaucomatous disc in infants: a suggested hypothesis for disc cupping. Trans Am Acad Ophthalmol Otolaryngol 1969;73:929-35.

3. Spaeth GL, Fernandes E, Hitchings RA. The pathogenesis of transient or permanent improvement in the appearance of the optic disc following glaucoma surgery. Doc Ophthalmol Proc Ser 1980;22:111-25.

4. Shin DH, Bielik M, Hong YJ, et al. Reversal of glaucomatous optic disc cupping in adult patients. Arch Ophthalmol 1989;107:1599-603

5. Katz LJ, Spaeth GL, Cantor LB, et al. Reversible optic disk cupping and visual field improvement in adults with glaucoma. Am J Ophthalmol 1989;107:485-92.

6. Raitta C, Tomita G, Vesti E, Harju M, Nakao H. Optic disc topography before and after trabeculectomy in advanced glaucoma. Ophthalmic Surg Lasers 1996;27:349-54.

7. Varma R, Spaeth GL, Katz LJ, Steinmann WC. Effect of acute pressure-lowering on the glaucomatous optic disc. Invest Ophthalmol Vis Sci (Suppl) 1988;29:354.

8. Funk J. Increase of neuroretinal rim area after surgical intraocular pressure reduction. Ophthalmic Surg 1990;21:585-8.

9. Irak I, Zangwill L, Garden V, et al. Change in optic disk topography after trabeculectomy. Am J Ophthalmol 1996;122:690-5

10. Azuara-Blanco A, Harris A, Cantor LB, Abreu MM, Weinland M. Effects of short term increase of intraocular pressure on optic disc cupping. Br J Ophthalmol 1998;83:880-3.

11. Lesk MR, Spaeth GL, Azuara-Blanco A, Araujo SV, Katz LJ, Terebuh AK, et al. Reversal of optic disc cupping after glaucoma surgery analyzed with a scanning laser tomograph. Ophthalmology 1999;106:1013-8.

12. Varma R, Quigley HA, Pease ME. Changes in optic disk characteristics and the number of nerve fibers in experimental glaucoma. Am J Ophthalmol 1992;114:554-9.

13. Drance SM. Studies in the susceptibility of the eye to raised intraocular pressure. Arch Ophthalmol 1962;68:478-85.

14. Paterson G. Effect of intravenous acetazolamide on relative arcuate scotomas and visual field in glaucoma simplex. Proc R Soc Med 1970;63:865-9.

15. Heilmann K. Progression and regression of visual field defects. In: Heilmann K, Richardson KT, editors. Glaucoma: conceptions of a disease. Stuttgart: Georg Thieme, 1978:168-75.

16. Greve EL, Furuno F, Verduin WM. The clinical significance of reversibility of glaucomatous visual field defects. Doc Ophthalmol 1979;19:197-203.

17. Phelps CD. Visual field defects in open-angle glaucoma: progression and regression. Doc Ophthalmol 1979;19:187-96.

18. Spaeth GL. Regression of optic nerve and visual field defects in glaucoma. In: Krieglstein GN, Leydhecker W, editors. Glaucoma update II. Berlin: Springer, 1983:81-2.
19. Spaeth GL. The effect of change in intraocular pressure on the natural history of glaucoma: lowering intraocular pressure in glaucoma can result in improvement of visual fields. Trans Ophthalmol Soc UK 1985;104:256-64.

20. Trible JR, Anderson DR. Factors associated with intraocular pressure-induced acute visual field depression. Arch Ophthalmol 1997;115:1523-7.

21. Glaucoma Laser Trial Research Group (Spaeth GL, et al.). The Glaucoma Laser Trial (GLT) and Glaucoma Laser Trial Follow-up Study. 7. Results. Am J Ophthalmol 1995;120:718-31.

22. Gandham S, Spaeth GL, Katz LJ. The Glaucoma Laser Trial. In: Kertes PJ, Conway MD, editors. Clinical trials in ophthalmology: a summary and practice guide. Baltimore: Williams \& Wilkins, 1998:305-20.

23. Quigley HA. The pathogenesis of reversible cupping in congenital glaucoma. Am J Ophthalmol 1977;84:358-70.

24. Hetherington JJr, Shaffer RN, Hoskins HD. The disc in congenital glaucoma. In: Etienne R, Patterson GD, editors. International glaucoma symposium, Albi. Diffusion Generale de Librairie, Marseille, 1975:127-43.

25. Jonas JB, Budde WM, Panda-Jonas S. Ophthalmoscopic evaluation of the optic nerve head. Surv Ophthalmol 1999;43:293-320.

26. Dolman CL, McCormick AQ, Drance SM. Aging of the optic nerve. Arch Ophthalmol 1980;98:2053-8.

27. Quigley HA, Dorman-Pease ME, Brown AE. Quantitative study of collagen and elastin of the optic nerve head and sclera in humans and experimental monkey glaucoma. Curr Eye Res 1991;10:877-88.

28. Quigley HA, Pease ME, Thibault D. Change in the appearance of elastin in the lamina cribrosa of glaucomatous optic nerve heads. Graefes Arch Clin Exp Ophthalmol 1994;232:257-61.

29. Pena JD, Netland PA, Vidal I, Dorr DA, Rasky A, Hernandez MR. Elastosis of the lamina cribrosa in glaucomatous optic neuropathy. Exp Eye Res 1998;67:517-24.

30. Levy NS, Crapps EE, Bonney RC. Displacement of the optic nerve head: response to acute intraocular pressure elevation in primate eyes. Arch Ophthalmol 1981;99:2166-74.

31. Yan DB, Flanagan JG, Farra T, Trope GE, Ethier CR. Study of regional deformation of the optic nerve head using scanning laser tomography. Curr Eye Res 1998;17:903-16.

32. Burgoyne CF, Quigley HA, Thompson HW, Vitale S, Varma $R$. Measurement of optic disc compliance by digitized image analysis in the normal monkey eye. Ophthalmology 1995;102:1790-9.

33. Burgoyne CF, Quigley HA, Thompson HW, Vitale S, Varma R. Early changes in optic disc compliance and surface position in experimental glaucoma. Ophthalmology 1995;102:1800-9.

34. Morgan JE, Jeffery G, Foss AJE. Axon deviation in the human lamina cribrosa. Br J Ophthalmol 1998;82:680-3.

35. Findl O, Strenn K, Wolzt M, Menapace R, Vass C, Eichler $\mathrm{HG}$, et al. Effects of changes in intraocular pressure on human ocular haemodynamics. Curr Eye Res 1997;16:1024-9.

36. Pillunat LE, Anderson DR, Knighton RW, Joos KM, Feuer WJ. Autoregulation of human optic nerve head blood flow in response to acute changes in ocular perfusion pressure. Exp Eye Res 1997;64:737-44.

37. Harris A, Ciulla TA, Chung HS, Martin B. Regulation of retinal and optic nerve blood flow. Arch Ophthalmol 1998;116:1491-5.

38. Hayreh SS, Bill A, Sperber GO. Effects of high intraocular pressure on the glucose metabolism in the retina and optic nerve in old atherosclerotic monkeys. Graefes Arch Clin Exp Ophthalmol 1994;232:745-52. 
39. Trible JR, Costa VP, Sergott RC, Spaeth GL, et al. The influence of primary open-angle glaucoma upon the retrobulbar circulation: baseline, postoperative and reproducibility analysis. Trans Am Ophthalmol Soc 1993;91:245-65.

40. Spaeth GL. Pathogenesis of visual loss in glaucoma: contributions and indications for fluorescein angiography. New York: Grune and Stratton, 1977.

41. Anderson DR, Cynader MS. Glaucomatous optic nerve cupping as an optic neuropathy. Clin Neurosci 1997;4:274-8.

42. Quigley HA, Hohman RM, Sanchez RM, Addicks EM. Optic nerve head blood flow in chronic experimental glaucoma. Arch Ophthalmol 1985;103:956-62.

43. Caprioli J, Miller JM. Optic disc area is related to disc size in normal subjects. Arch Ophthalmol 1987;105:1283-5.

44. Balazsi AG, Rootman J, Drance SM, Schulzer M, Douglas GR. The effect of age on the nerve fiber population of the human optic nerve. Am J Ophthalmol 1984;97:760-6.

45. Funk J, Dieringer T, Grehn F. Correlation between neuroretinal rim area and age in normal subjects. Graefes Arch Clin Exp Ophthalmol 1989;227:544-8.

46. Tsai CS, Ritch R, Shin DH, Wan JY, Chi T. Age-related decline of disc rim areas in visually normal subjects. Ophthalmology 1992;99:29-35.

47. Repka MX, Quigley HA. The effect of age on normal human optic nerve fiber number and diameter. Ophthalmology 1989;96:26-32.

48. Varma R, Tielsch JM, Quigley HA, et al. Race-, age-, genderand refractive error-related differences in the normal optic disc. Arch Ophthalmol 1994;112:1068-76.

49. Hernandez MR, Luo XX, Igoe F, et al. Extracellular matrix of the human lamina cribrosa. Am J Ophthalmol 1987;104:567-76.

50. Morgan J. Optic nerve head structure in glaucoma: astrocytes as mediators of axonal damage. Eye 2000;14:437-44.

51. Topouzis F, Peng F, Kotas-Neumann R, Garcia R, Sanguinet J, Yu F, Coleman AF. Longitudinal changes in optic disc topography of adult patients after trabeculectomy. Ophthalmology 1999;106:1147-51.

52. Burgoyne CF, Varma R, Quigley HA, Vitale S, Pease ME, Lenane PL. Global and regional detection of induced optic disc change by digitized image analysis. Arch Ophthalmol 1994;112:261-8.

53. Yucel YH, Gupta N, Kalichman MW, Mizisin AP, Hare W, Lima MD, et al. Relationship of optic disc topography to optic nerve fiber number in glaucoma. Arch Ophthalmol 1998;116:493-7.

54. Iester M, Courtright $P$, Mikelberg FS. Retinal nerve fiber layer height in high-tension glaucoma and healthy eyes. J Glaucoma 1998;7:1-7.
55. Sogano S, Tomita G, Kitazawa Y. Changes in retinal nerve fiber layer thickness after reduction of intraocular pressure in chronic open-angle glaucoma. Ophthalmology 1993;100:1253-8.

56. Lietz A, Hendrickson P, Flammer J, Orgul S, Haefliger IO. Effect of carbogen, oxygen and intraocular pressure on Heidelberg Retina Flowmeter parameter 'flow' measured at the papilla. Ophthalmologica 1998;212:149-52.

57. Harris A, Ciulla TA, Kagemann L, Zarfati D, Martin B. Vasoprotection as neuroprotection for the optic nerve. Eye 2000;14:473-5.

58. Bill A. Vascular physiology of the optic nerve. In: Varma R, Spaeth GL, Parker KW, editors. The optic nerve in glaucoma. Philadelphia: JB Lippincott, 1993:37-50.

59. Minckler DS. Neuronal damage in glaucoma. In: Varma R, Spaeth GL, Parker KW, editors. The optic nerve in glaucoma. Philadelphia: JB Lippincott, 1993:51-9.

60. Schwartz B, Nagin P. Fluorescein angiography of the optic disc. In: Varma R, Spaeth GL, Parker KW, editors. The optic nerve in glaucoma. Philadelphia: JB Lippincott, 1993:307-24.

61. Hitchings RA, Spaeth GL. The optic disc in glaucoma. I. Classification. Br J Ophthalmol 1976;60:778-85.

62. Spaeth GL. Appearances of the optic disc in glaucoma: a pathogenic classification. In: New Orleans Academy of Ophthalmology: a symposium on glaucoma. St Louis: CV Mosby, 1981:114-53.

63. Grant WM, Burke JF Jr. Why do some people go blind from glaucoma? Ophthalmology 1982;89:991-8.

64. Gliklich RE, Steinmann WC, Katz LJ, et al. Primary openangle glaucoma and visual field changes. Invest Ophthalmol Vis Sci 1987;12:63.

65. Rahmani B, Tielsch JM, Katz J, Gottsch J, Quigley H, Javitt J, et al. The cause-specific prevalence of visual impairment in an urban population. The Baltimore Eye Survey. Ophthalmology 1996;103:1721-6.

66. Hattenhauer MG, Johnson DH, Ing HH, Herman DC, Hodge DO, Yawn BP, et al. The probability of blindness from openangle glaucoma. Ophthalmology 1998;105:2099-104.

67. Spaeth GL. Improvement in disc appearance is associated with improved long-term prognosis. Presented at the Joint Meeting of the American Glaucoma Society and European Glaucoma Society, Iceland.

68. Spaeth GL, Fellman RL, Starita RL, et al. A new management system for glaucoma based on improvement of the appearance of the optic disc or visual field. Trans Am Acad Ophthalmol Otolaryngol 1985;83:269-84.

69. Spaeth GL. A new management system for glaucoma based on improvement of the appearance of the optic disc or visual field. Fortschr Ophthalmol 1988;85:614-9. 